\title{
CORRELATION BETWEEN FACTORS RELATED TO THE STIMULATION OF THE SELF-ESTEEM AT PRESCHOOL CHILDREN IN KINDERGARTEN
}

\author{
Joško Sindik, $P h D$ \\ University of Dubrovnik, Dubrovnik (Croatia) \\ e-mail: josko.sindik@hinet.hr \\ Dijana Frančešević, graduated psychologist \\ Kindergarten «Kustošija», Zagreb (Croatia) \\ Narcisa Vojnović, M.S. \\ Education and Teacher Training Agency, Zagreb (Croatia) \\ Ida Šimunović, graduated psychologist \\ Kindergarten "Tratinčica”, Koprivnica (Croatia)
}

\begin{abstract}
A b s tract
Self-esteem, an important aspect of self-concept, is the term which expresses the global evaluation of oneself. Coordinated stimulation of child's development of self-esteem of children by parents and kindergarten is an important prerequisite for a child's overall mental and physical development. The aim of this article relates to the determination of intercorrelations within a sets of variables and crosscorrelations between sets of variables: the type of information that parents receive from the educator in the kindergarten, kindergarten's assistance in developing self-esteem of the child, parental encouraging of the child's self-esteem and a source of knowledge about the development of self-esteem in children. Participants were occasional sample of 102 mothers who had children involved in preschool programs in Croatia, in December 2009. We applied the Questionnaire about parental perception of encouraging selfesteem in kindergarten. With the exception of sources of knowledge about the child's self-esteem, a statistically significant correlation is found among all other sets of variables related to the promotion of the child's self-esteem. On the other hand, a small number of statistically significant correlations is found between different sets of variables. So, only the types of information that parents receive from the educator of the child are significantly correlated with different sources of knowledge about the child's self-esteem, but also with the information that they give teachers about the child. The results show that mothers generally show interest in developing self-esteem in children, and that they perceive the importance of their own (parental) roles, the importance of kindergarten, but also the coordination of joint efforts of parents and kindergarten experts, all for the purpose of stimulating the child's self-esteem.
\end{abstract}

Keywords: children, self-esteem, relationship, kindergarten, parents 


\section{Introduction}

Self-concept represents descriptive aspect of self and cognitive schema in which the information about oneself is organized. In the theories that define self-concept as a cognitive scheme in which information about themselves is organized, which also controls the processing of information relevant to the self-concept, the self-esteem is distinguished as a central aspect of self. Self-esteem is a term which expresses a global evaluation of oneself.

Rosenberg (1965) defines self-esteem as a positive or negative attitude towards oneself, and he is one of the most important authors of the early empirical studies on the factors that precede self-esteem. His studies resulted in the interpretation of social conditions and subjective experiences that are related to increasing or decreasing selfesteem. For example, the amount of parental attention and interest for the child are significantly correlated with child's self-esteem (Rosenberg, 1965, 1968).

Coopersmith (1967) under the self-esteem implies the evaluation by which the individual reflects the attitude about (non)acceptance of himself, which indicates the degree of belief in the individual's own ability, importance, performance or value. Exploring factors that affect self-esteem, he found that children who reported high selfesteem were more creative, assertive, and more resistant to the environmental influences that were not in accordance with their own observations, and children were more flexible and solve problems in ways more original than children with low selfesteem.

In researches in which it was studied the relationship between social conditions and subjective experiences with self-esteem, Rosenberg (1965) found that the amount of parental attention and interest of the child were significantly correlated with selfesteem. Subjects with high self-esteem are more resistant to environmental influences that are not in accordance with their own observations, they are more flexible and imaginative, and solve problems in more original ways than individuals with low selfesteem. Subjective assessment of self-esteem is associated with different manifestations of the behavior of individuals (Rosenberg and Pearl, 1978). Based on a series of investigations, it was found that a key role in developing self-esteem was the atmosphere in the parental home and the immediate social environment (Felson and Zielinski, 1989). The key role of parents in developing self-esteem is not surprising, considering that the family is the first social group in which the child is involved after birth and in which he/she first gained experience, forms attitudes, develops his/her personal resources and interpersonal relationships (Collins \& Russell, 1991, Darling and Steinberg, 1993). The family is a significant factor in the development because of its impact on the child for a long period of time. Nowadays, another important factor in the socialization of the child is the attendance in kindergarten (Harter, 1999). Because of the current trends and dynamics of parental life a child most of his daytime spends in the kindergarten. Kindergarten thus takes an important educational role in a child's life. Kindergarten is a community resource that should help and encourage parents in educational efforts. Many scientific researches in the field of the effects of cooperation between family and kindergarten in the education and stimulating child development 
show that a strong relationship between these two social contexts supports the child's developmental potential.

For example, Bronfenbrenner (1979, in Edeiman, 1994) found that both factors (parents and institutional preschool programs) have an important role in the lives of children and the development potential of the educational situation has grown with the number of supportive relationships between this situation and other contexts involving a child or a person responsible for his supporting in the growth. In other words, ensuring the continuity and mutual connection of the family and preschool institution, has a perspective for greater quality of the educational impact on a child (Peterson and Rollins, 1987). Conversely, if the family and child care do not establish cooperation, do not exchange information about the child and act completely separated, we talk about education in discontinuity. In such a case it is reasonable to assume that the discrepancy in the educational activity adversely affects the child's development. In the research which investigated the willingness of parents to cooperate with the preschool institution, the results show that parents are greatly interested in how their children spend a day in the kindergarten, and in which activities are involved (Petrovic Sočo, 1995).

Accordingly, in this paper, we aim to investigate the relationships between: parental ways of encouraging self-esteem at children, knowledge sources which are used to encourage self-esteem of the child, how parents perceive the help of a kindergarten in the development of self-esteem and in which extent parents cooperate with educators, regarding the transfer of essential information about the child.

\section{Aims and problems}

The aim of this study is to identify the intercorrelations within the sets of variables and the crosscorrelations between sets of variables: the type of information that parents receive from educators in the kindergarten, kindergarten assistance in developing self-esteem of the child, parental stimulating self-esteem, and sources of knowledge about the development of self-esteem in children.

In line with the main aim of the research, we formulate two sets of problems:

1) To examine the relationship within the variables (intercorrelations): what kind of information parents receive from educators in the kindergarten, how kindergarten helps the child to develop self-esteem, parental stimulating self-esteem, sources of knowledge about the development of self-esteem in children. We hypothesized that there are significant correlations within sets of variables: the type of information that parents receive from educators in the kindergarten, kindergarten assistance in developing self-esteem of the child, parental encouragement of self-esteem in children; sources of knowledge about the development of self-esteem in children. These assumptions are founded on the fact that the choice of specific variables from a given set may to some extent imply the choice of the other kinds of variables from the same group (e.g. holding that a particular type of a kindergarten's assistance to help the child 
to develop self-esteem is extremely useful, may imply that other types of help are also important).

2) To examine the relationship between the variables (crosscorrelations): what kind of information parents receive from educators in the kindergarten, how kindergarten helps the child to develop self-esteem, parental stimulating self-esteem, sources of knowledge about the development of self-esteem in children. We hypothesized that there are no statistically significant correlations between sets of variables: the type of information that parents receive from educators in kindergarten, parental encouragement of self-esteem in children; types of kindergarten's helping children in developing self-esteem; sources of knowledge about the development of self-esteem in children. These assumptions are founded on the fact that the sets of variables simply refer to the areas of attitudes and opinions about fostering a child's self-esteem, which does not depend on each other.

\section{Methods}

The study is the correlation type.

\section{Participants}

Participants were convenient sample of mothers who had children involved in preschool programs in Croatia, during December 2009. In total, the study involved 102 mothers. Although there was a real possibility that the questionnaire was completed by mothers who were somewhat motivated in relation to the researched topic, and slightly more educated (using Internet). However, the size of the sample can consider the sample as somewhat representative for the population of children's mothers whose preschoolers are from Croatian urban environment, and are attending the preschool educational institution.

\section{Measuring instruments}

The questionnaire about parental perception of encouraging self-esteem in the kindergarten is made by Simunovic (2007). The questionnaire consists of several parts. The first section contained basic demographic information about the child (age, gender). In the second part there were questions with the Likert scale ranging from 1 to 3 ( $3=$ often, 2 = occasionally, 1 = rarely, never): a) sources of knowledge about the development of self-esteem in children (5 items) b) type of assistance from the kindergarten to the development of self-esteem (5 items) c) encouraging parental selfesteem in children (4 items) d) information that parents receive from the educator of the child (4 items). Finally, the third part of the questionnaire were four questions related to the success of parental encouraging child's self-esteem $(0=$ none, $1=$ partial, $2=$ yes $)$ levels of self-satisfaction with their child $(0=$ not, $1=$ we are, but would like to see their child more persistent, 2 =yes), whether the kindergarten was doing enough in 
terms of developing self-esteem of the child $(0=$ no, $1=$ do not know, $2=$ yes $)$ the extent to inform parents about the kindergarten level, and encouraging self-esteem of children $(0=$ almost never, $1=$ sometimes, $2=$ yes, regularly). The full questionnaire is given in the attachment.

\section{Procedure}

The questionnaire was conducted anonymously and with the guidance to parents, e.g. mothers, that they honestly answer the questions from the questionnaire. Mothers filled in the questionnaire online, using web-apps Survey Monkey, which is advertised on the web site Roda (www.roda.hr) in December 2009. Estimated time of the questionnaire was limited to one week. The data were analyzed using statistical software package SPSS 16.0.

\section{Results and Discussion}

Table 1 shows that the average age of children whose mothers were tested were slightly less than 5 . For the main study variables, all distributions significantly deviate from the normal distribution. However, due to the fact that there are no bimodal distributions, and that they are symmetrical, we considered correct to use parametric methods of data processing (Pearson correlations).

In terms of average values, among the sources of knowledge about self-esteem of the child, mothers perceived that the parental 'intuition', together with knowledge from the professional and popular literature, are the best indicators of a child's self-esteem. The educators in the kindergarten and members of the professional team have the relatively minor role, and the minimum role have only parents and their way of upbringing of the child.

Help from the kindergarten in developing child's self-esteem is the greatest one through proper educators' behavior towards children (probably in the direction appropriate to encourage the child's progress in the psycho-physical development), and then through often high-quality information given to parents about the behavior of their child in the kindergarten. The minimum number of parents believe that the help of the kindergarten is not required to encourage the development of self-esteem in children (i.e., hardly anyone denies the importance of education in kindergarten children to develop self-esteem). The kindergarten teachers usually provide information regarding the child's relationship with other children in the kindergarten's educational group, and about the independence of the child. At least they provide information regarding the successes and failures of the child (probably because they are feared about negative reactions of parents in cases of undesirable behavior of the child or when they failed to carry out tasks). Parental encouraging self-esteem was assessed as the most successful in expressing their opinion, enabling the child to know what is good and what is not. However, the remaining two ways of parental encouraging self-esteem were rated as very effective. Regarding the remaining variables of the questionnaire, parental self- 
assessment of their success in encouraging self-esteem is somewhat above the theoretical average; hence parents are generally very satisfied with the level of encouraging self-esteem of their child. Satisfaction with the overall level of self-esteem of a child is even greater, so parents feel that children at a relatively high degree have developed self-esteem. Assessment of doing daycare in the direction of encouraging self-esteem is somewhat lower than estimates of their own (parents') contributions to fostering self-esteem, but above the theoretical average. Finally, only the extent to which teachers inform parents about the self- esteem of children in the kindergarten is slightly below the theoretical average. In this aspect, the greatest possible progress could be made.

Table 1 Descriptive statistics for all items in the measuring instrument

\begin{tabular}{|c|c|c|c|c|c|}
\hline Variable group & Variable & $\begin{array}{c}\text { Arithmetic } \\
\text { Mean }\end{array}$ & $\begin{array}{c}\text { Standard } \\
\text { Deviation }\end{array}$ & $\begin{array}{l}\text { Kolmogorov- } \\
\text { Smirnov Z }\end{array}$ & Sig. (p) \\
\hline \multicolumn{2}{|l|}{ Child's age } & 4,84 & 1,45 & 1,816 & $<0,01$ \\
\hline \multirow{5}{*}{$\begin{array}{l}\text { Source of } \\
\text { knowledge about } \\
\text { the development } \\
\text { of self-esteem... }\end{array}$} & $\begin{array}{l}\text { parents and their way } \\
\text { of education }\end{array}$ & 1,49 & 0,63 & 3,655 & $<0,01$ \\
\hline & $\begin{array}{l}\text { professional and } \\
\text { popular literature }\end{array}$ & 2,38 & 0,66 & 3,085 & $<0,01$ \\
\hline & parent's intuition & 2,71 & 0,52 & 4,544 & $<0,01$ \\
\hline & $\begin{array}{l}\text { teachers in } \\
\text { kindergarten }\end{array}$ & 1,70 & 0,69 & 2,789 & $<0,01$ \\
\hline & professional team & 1,28 & 0,51 & 4,593 & $<0,01$ \\
\hline \multirow{5}{*}{$\begin{array}{l}\text { Kindergarten's } \\
\text { assistance in } \\
\text { developing self- } \\
\text { esteem... }\end{array}$} & $\begin{array}{l}\text { proper teacher's } \\
\text { treatment of children }\end{array}$ & 2,53 & 0,64 & 3,804 & $<0,01$ \\
\hline & $\begin{array}{l}\text { often provide good } \\
\text { quality information }\end{array}$ & 2,31 & 0,73 & 2,996 & $<0,01$ \\
\hline & $\begin{array}{l}\text { advice from the expert } \\
\text { team }\end{array}$ & 1,76 & 0,75 & 2,713 & $<0,01$ \\
\hline & $\begin{array}{l}\text { parental meetings on a } \\
\text { particular topic }\end{array}$ & 1,89 & 0,74 & 2,266 & $<0,01$ \\
\hline & $\begin{array}{l}\text { no need for help from } \\
\text { the kindergarten }\end{array}$ & 1,58 & 0,64 & 3,216 & $<0,01$ \\
\hline \multirow{4}{*}{$\begin{array}{l}\text { The kindergarten } \\
\text { teachers } \\
\text { provided } \\
\text { information } \\
\text { regarding... }\end{array}$} & $\begin{array}{l}\text { problem solving and } \\
\text { effort }\end{array}$ & 2,05 & 0,79 & 2,217 & $<0,01$ \\
\hline & independence & 2,22 & 0,82 & 2,955 & $<0,01$ \\
\hline & $\begin{array}{l}\text { reactions to success } \\
\text { and failure }\end{array}$ & 1,95 & 0,84 & 2,470 & $<0,01$ \\
\hline & $\begin{array}{l}\text { relationship with other } \\
\text { children }\end{array}$ & 2,25 & 0,75 & 2,825 & $<0,01$ \\
\hline \multirow{4}{*}{$\begin{array}{l}\text { Parents } \\
\text { encouraging } \\
\text { self-esteem } \\
\text { through ... }\end{array}$} & $\begin{array}{l}\text { express their own } \\
\text { opinions }\end{array}$ & 2,85 & 0,38 & 5,174 & $<0,01$ \\
\hline & $\begin{array}{l}\text { investment the effort } \\
\text { into what a child does }\end{array}$ & 2,59 & 0,53 & 3,918 & $<0,01$ \\
\hline & $\begin{array}{l}\text { enabling child to know } \\
\text { what is good }\end{array}$ & 2,74 & 0,49 & 4,665 & $<0,01$ \\
\hline & $\begin{array}{l}\text { setting realistic } \\
\text { expectations }\end{array}$ & 2,67 & 0,49 & 4,307 & $<0,01$ \\
\hline
\end{tabular}




\begin{tabular}{|l|c|c|c|c|}
\hline $\begin{array}{l}\text { Parental self-assessment of the success in } \\
\text { stimulation self-esteem }\end{array}$ & 1,22 & 0,41 & 4,882 & $<0,01$ \\
\hline $\begin{array}{l}\text { Satisfaction with the overall level of self- } \\
\text { esteem of the child }\end{array}$ & 1,40 & 0,65 & 3,150 & $<0,01$ \\
\hline $\begin{array}{l}\text { Assessment of doing kindergarten in } \\
\text { stimulating self-esteem }\end{array}$ & 1,18 & 0,67 & 2,837 & $<0,01$ \\
\hline $\begin{array}{l}\text { The extent to which teachers inform about } \\
\text { self-esteem of children in kindergarten }\end{array}$ & 0,82 & 0,72 & 2,377 & $<0,01$ \\
\hline
\end{tabular}

\section{Intercorrelations within groups of variables}

Table 2 shows the intercorrelations in the set of variables Information that parents receive from teachers about the child. All correlations were statistically significant with $p<.01$, positive and moderately high. Thus, the information that parents receive about the child from the teachers, kindergarten teachers, is given or not at all examined aspects of child development, or in all aspects of its' behavior. In other words, according to the mothers' opinions, kindergarten teachers are prone to relatively uniformly inform parents about all areas of his/her development, or forms of behaviors.

Table 2 Intercorrelations of variables in the set Information that parents receive from teachers about a child

\begin{tabular}{|l|c|c|c|c|}
\hline \multicolumn{1}{|c|}{ Variable } & $\begin{array}{c}\text { problem } \\
\text { solving and } \\
\text { effort }\end{array}$ & independence & $\begin{array}{c}\text { reactions to } \\
\text { success and } \\
\text { failure }\end{array}$ & $\begin{array}{c}\text { relationship with } \\
\text { other children }\end{array}$ \\
\hline $\begin{array}{l}\text { problem solving } \\
\text { and effort }\end{array}$ & 1 & $0,630^{* *}$ & $0,679^{* *}$ & $0,595^{* *}$ \\
\hline independence & 1 & $0,668^{* *}$ & $0,666^{* *}$ \\
\hline $\begin{array}{l}\text { reactions to } \\
\text { success and } \\
\text { failure }\end{array}$ & & 1 & $0,679^{* *}$ \\
\hline $\begin{array}{l}\text { relationship with } \\
\text { other children }\end{array}$ & & & & 1 \\
\hline
\end{tabular}

** correlation significant with $p<0,01$

Table 3 shows the intercorrelations of variables in the set of variables Kindergarten's assistance in the development of self-esteem in children. Almost all the correlations ( 9 , of a possible 10) between the variables related to positive kindergarten's engagement related to children's self-esteem, were statistically significant with $p<.01$, positive and moderately high. On the other hand, the correlations of these variables with an attitude that help from the kindergarten is not required in the development of the child's self-esteem, are negative, low and statistically significant, except for one variable (giving information about the child), with which the relationship is statistically insignificant. 
In other words, according to the mothers, experts in kindergarten tend to relatively uniformly assist parents in different ways.

Table 3 Intercorrelations of variables in the set of variables Kindergarten's assistance in the development of self-esteem in children

\begin{tabular}{|l|c|c|c|c|c|}
\hline \multicolumn{1}{|c|}{ Variable } & $\begin{array}{c}\text { proper } \\
\text { teacher's } \\
\text { treatment of } \\
\text { children }\end{array}$ & $\begin{array}{c}\text { often provide } \\
\text { good quality } \\
\text { information }\end{array}$ & $\begin{array}{c}\text { advice } \\
\text { from the } \\
\text { expert } \\
\text { team }\end{array}$ & $\begin{array}{c}\text { parental } \\
\text { meetings on } \\
\text { a particular } \\
\text { topic }\end{array}$ & $\begin{array}{c}\text { no need for } \\
\text { help from } \\
\text { the } \\
\text { kindergarten }\end{array}$ \\
\hline $\begin{array}{l}\text { proper teacher's } \\
\text { treatment of } \\
\text { children }\end{array}$ & 1 & $0,657^{* *}$ & $0,449^{* *}$ & $0,496^{* *}$ & $-224^{*}$ \\
\hline $\begin{array}{l}\text { often provide } \\
\text { good quality } \\
\text { information }\end{array}$ & & 1 & $0,481^{* *}$ & $0,518^{* *}$ & $-0,160$ \\
\hline $\begin{array}{l}\text { advice from the } \\
\text { expert team }\end{array}$ & & & 1 & $0,703^{* *}$ & $-0,273^{* *}$ \\
\hline $\begin{array}{l}\text { parental } \\
\text { meetings on a } \\
\text { particular topic }\end{array}$ & & & & 1 & $-0,265^{* *}$ \\
\hline $\begin{array}{l}\text { no need for help } \\
\text { from the } \\
\text { kindergarten }\end{array}$ & & & & & 1 \\
\hline
\end{tabular}

$* *$ correlation significant with $p<0,01 ; *$ correlation significant with $p<0,05$

Table 4 Intercorrelations of variables in the set of variables Parental encouraging self-esteem in children

\begin{tabular}{|l|c|c|c|c|}
\hline \multicolumn{1}{|c|}{ Variable } & $\begin{array}{c}\text { express } \\
\text { their own } \\
\text { opinions }\end{array}$ & $\begin{array}{c}\text { investment the } \\
\text { effort into } \\
\text { what a child } \\
\text { does }\end{array}$ & $\begin{array}{c}\text { Enabling the } \\
\text { child to know } \\
\text { what is good }\end{array}$ & $\begin{array}{c}\text { setting } \\
\text { realistic } \\
\text { expectations }\end{array}$ \\
\hline $\begin{array}{l}\text { express their own } \\
\text { opinions }\end{array}$ & 1 & $0,234^{*}$ & $0,268^{* *}$ & $0,419^{* *}$ \\
\hline $\begin{array}{l}\text { investment the } \\
\text { effort into what a } \\
\text { child does }\end{array}$ & 1 & $0,301^{* *}$ & 0,150 \\
\hline $\begin{array}{l}\text { enabling child to } \\
\text { know what is } \\
\text { good }\end{array}$ & & 1 & 0,124 \\
\hline $\begin{array}{l}\text { setting realistic } \\
\text { expectations }\end{array}$ & & & & 1 \\
\hline
\end{tabular}

** correlation significant with $p<0,01 ; *$ correlation significant with $p<0,05$

Table 4 shows the intercorrelations in the set of variables Parental encouraging self-esteem in children. Four correlations between variables that are related to ways of encouraging the parental encouraging child's self-esteem were statistically significant, positive and low (except for two insignificant, setting realistic expectations in relation 
to a child: with an investment of effort in what child is doing and making it clear what is good). In other words, according to mothers, parents to some extent tend to encourage development of child's self-esteem relatively uniformly in different ways.

Table 5 shows the intercorrelations in the set of variables Source of knowledge about the development of self-esteem in children

Only one correlation, among all the variables related to sources of knowledge about the development of self-esteem in children is statistically significant, positive medium and high (remaining ones are statistically insignificant): association of educators and members of the professional team as a source of knowledge about the development of self-esteem. In other words, the opinion of mothers is that all factors associated with the kindergarten are uniformly similar sources of knowledge about the status of the self-esteem in children.

Table 5 Intercorrelations of variables in the set of variables Source of knowledge about the development of self-esteem in children

\begin{tabular}{|l|c|c|c|c|c|}
\hline \multicolumn{1}{|c|}{ Variable } & $\begin{array}{c}\text { parents and } \\
\text { their way of } \\
\text { education }\end{array}$ & $\begin{array}{c}\text { professional and } \\
\text { popular } \\
\text { literature }\end{array}$ & $\begin{array}{c}\text { parent's } \\
\text { intuition }\end{array}$ & $\begin{array}{c}\text { teachers in } \\
\text { kindergarten }\end{array}$ & $\begin{array}{c}\text { professional } \\
\text { team }\end{array}$ \\
\hline $\begin{array}{l}\text { parents and their } \\
\text { way of education }\end{array}$ & 1 & $-0,003$ & 0,052 & $-0,111$ & $-0,037$ \\
\hline $\begin{array}{l}\text { professional and } \\
\text { popular literature }\end{array}$ & 1 & $-0,015$ & $-0,069$ & $-0,032$ \\
\hline parent's intuition & & & 1 & 0,136 & $-0,092$ \\
\hline $\begin{array}{l}\text { teachers in } \\
\text { kindergarten }\end{array}$ & & & & 1 & $0,415^{* *}$ \\
\hline $\begin{array}{l}\text { professional } \\
\text { team }\end{array}$ & & & & 1 \\
\hline
\end{tabular}

** correlation significant with $p<0,01$

\section{Correlation between sets of variables}

Table 6 shows the relationship between sets of variables Sources of knowledge about the development of self-esteem in children and Kindergarten's assistance in the development of self-esteem in children. From a total of 25 correlations, 6 are statistically significant. Among the sources of knowledge about the development of self-esteem in children, the largest number of statistically significant positive (albeit low) correlations has a professional team, whose information is correlated to the proper behavior of teachers towards children, frequent and quality providing information, counselling by members of the expert team. Equal size and direction of the correlation has information given by teachers in the kindergarten. It appears that the structure of parental meetings on specific topics affects less need of the mothers to use a professional literature. On average, these two sets of variables are relatively weakly correlated. 
Table 6 Cross-correlations between sets of variables Source of knowledge about the development of self-esteem in children and Kindergarten's assistance in the development of self-esteem in children

\begin{tabular}{|l|c|c|c|c|c|}
\hline \multicolumn{1}{|c|}{ Variable } & \multicolumn{5}{c|}{ Kindergarten's assistance in developing self-esteem } \\
\hline $\begin{array}{l}\text { Source of } \\
\text { knowledge about } \\
\text { the development } \\
\text { of self-esteem }\end{array}$ & $\begin{array}{c}\text { proper } \\
\text { teacher's } \\
\text { treatment with } \\
\text { children }\end{array}$ & $\begin{array}{c}\text { often } \\
\text { provide } \\
\text { good quality } \\
\text { information }\end{array}$ & $\begin{array}{c}\text { advice } \\
\text { from the } \\
\text { expert } \\
\text { team }\end{array}$ & $\begin{array}{c}\text { parental } \\
\text { meetings on } \\
\text { a particular } \\
\text { topic }\end{array}$ & $\begin{array}{c}\text { no need for } \\
\text { help from the } \\
\text { kindergarten }\end{array}$ \\
\hline $\begin{array}{l}\text { parents and their } \\
\text { way of education }\end{array}$ & $-0,012$ & $-0,015$ & 0,080 & 0,051 & $-0,023$ \\
\hline $\begin{array}{l}\text { professional and } \\
\text { popular literature }\end{array}$ & $-0,179$ & $-0,148$ & $-0,177$ & $-0,197 *$ & 0,010 \\
\hline parent's intuition & $-0,063$ & $-0,015$ & $-0,078$ & 0,097 & 0,101 \\
\hline $\begin{array}{l}\text { teachers in } \\
\text { kindergarten }\end{array}$ & $0,325^{* *}$ & $0,212^{*}$ & 0,072 & 0,168 & $-0,160$ \\
\hline $\begin{array}{l}\text { professional } \\
\text { team }\end{array}$ & $0,230^{*}$ & $0,287^{* *}$ & $0,304 * *$ & 0,133 & $-0,114$ \\
\hline
\end{tabular}

$* *$ correlation significant with $p<0,01 ; *$ correlation significant with $p<0,05$

Table 7 Cross-correlations between sets of variables Source of knowledge about the development of self-esteem in children and Information that parents receive from teachers about the child

\begin{tabular}{|l|c|c|c|c|}
\hline \multicolumn{1}{|c|}{ Variable } & \multicolumn{3}{|c|}{ The kindergarten teachers provided information regarding } \\
\hline $\begin{array}{l}\text { Source of knowledge } \\
\text { about the development } \\
\text { of self-esteem }\end{array}$ & $\begin{array}{c}\text { problem } \\
\text { solving and } \\
\text { effort }\end{array}$ & independence & $\begin{array}{c}\text { reactions to } \\
\text { success and } \\
\text { failure }\end{array}$ & $\begin{array}{c}\text { relationship } \\
\text { with other } \\
\text { children }\end{array}$ \\
\hline $\begin{array}{l}\text { parents and their way } \\
\text { of education }\end{array}$ & 0,172 & $0,218^{*}$ & 0,141 & $0,257^{* *}$ \\
\hline $\begin{array}{l}\text { professional and } \\
\text { popular literature }\end{array}$ & $-0,055$ & $-0,173$ & $-0,073$ & $-0,098$ \\
\hline parent's intuition & $-0,013$ & 0,058 & $-0,056$ & 0,016 \\
\hline $\begin{array}{l}\text { teachers in } \\
\text { kindergarten }\end{array}$ & $0,412^{* *}$ & $0,366^{* *}$ & $0,405^{* *}$ & $0,438^{* *}$ \\
\hline professional team & $0,258^{* *}$ & $0,206^{*}$ & $0,285^{* *}$ & $0,271^{* *}$ \\
\hline
\end{tabular}

$* *$ correlation significant with $p<0,01 ; *$ correlation significant with $p<0,05$

Table 7 shows the relationship between sets of variables Sources of knowledge about the development of self-esteem in children and Information that parents receive from teachers about child. From a total of 20 correlations, 10 were statistically significant. Among the sources of knowledge about the development of self-esteem in children, the largest number of statistically significant positive (albeit low-to mediumhigh) correlations have kindergarten teachers in kindergartens, and (to a lesser extent) the professional team, whose information is correlated with all areas of child development and behavior. Information about the child's independence and relationships with other children correlated positively and significantly with the 
educational style of parents, teachers, and professional team as a source of knowledge about the child's self-esteem. On average, these two sets of variables are moderately well-correlated.

Table 8 shows the relationship between sets of variables Kindergarten's assistance in the development of self-esteem in children and Parental encouraging selfesteem in children. From a total of 20 correlations, only two were statistically significant. Proper teacher's treatment with children had a positive and significant (albeit low) correlation with setting realistic expectations of mothers. Investment the effort into what child does is low but positive and statistically significantly correlated with an attitude that help from the kindergarten is not required in encouraging the development of self-esteem of the child. On average, these two sets of variables are very weakly correlated.

Table 8. Correlations between sets of variables Kindergarten's assistance in the development of self-esteem in children and Parental encouraging selfesteem in children

\begin{tabular}{|l|c|c|c|c|c|}
\hline \multicolumn{1}{|c|}{ Variable } & \multicolumn{5}{|c|}{ Kindergarten's assistance in developing self-esteem } \\
\hline $\begin{array}{l}\text { Parental } \\
\text { encouraging } \\
\text { self-esteem } \\
\text { through ... }\end{array}$ & $\begin{array}{c}\text { proper } \\
\text { teacher's } \\
\text { treatment of } \\
\text { children }\end{array}$ & $\begin{array}{c}\text { often } \\
\text { provide } \\
\text { good quality } \\
\text { information }\end{array}$ & $\begin{array}{c}\text { advice } \\
\text { from the } \\
\text { expert } \\
\text { team }\end{array}$ & $\begin{array}{c}\text { parental } \\
\text { meetings on } \\
\text { a particular } \\
\text { topic }\end{array}$ & $\begin{array}{c}\text { no need for } \\
\text { help from the } \\
\text { kindergarten }\end{array}$ \\
\hline $\begin{array}{l}\text { express their } \\
\text { own opinions }\end{array}$ & 0,159 & 0,025 & 0,120 & 0,048 & $-0,013$ \\
\hline $\begin{array}{l}\text { investment the } \\
\text { effort into what } \\
\text { the child does }\end{array}$ & $-0,051$ & 0,030 & 0,102 & 0,012 & $0,242^{*}$ \\
\hline $\begin{array}{l}\text { enabling child } \\
\text { to know what is } \\
\text { good }\end{array}$ & $-0,054$ & $-0,043$ & $-0,064$ & $-0,107$ & 0,148 \\
\hline $\begin{array}{l}\text { setting realistic } \\
\text { expectations }\end{array}$ & $0,282 * *$ & 0,183 & 0,161 & 0,117 & 0,021 \\
\hline
\end{tabular}

** correlation significant with $p<0,01 ; *$ correlation significant with $p<0,05$

Table 9 shows the relationship between sets of variables Sources of knowledge about the development of self-esteem in children and Parental encouraging self-esteem in children. From a total of 20 correlations, only two were statistically significant. The information that provides educator in a kindergarten about the child's self-esteem, positive and significant (albeit low) correlated with setting realistic expectations of mothers. Investment the effort into what a child does is low but positive and statistically significantly correlated with consulting the professional literature. On average, these two sets of variables are very weakly correlated. 
Table 9 Correlations between sets of variables Parental encouraging self-esteem in children and Source of knowledge about the development of self-esteem in children

\begin{tabular}{|l|c|c|c|c|}
\hline \multicolumn{1}{|c|}{ Variable } & \multicolumn{4}{|c|}{ Parental encouraging self-esteem through ... } \\
\hline $\begin{array}{l}\text { Source of } \\
\text { knowledge about } \\
\text { the development of } \\
\text { self-esteem }\end{array}$ & $\begin{array}{c}\text { express } \\
\text { their own } \\
\text { opinions }\end{array}$ & $\begin{array}{c}\text { investment the } \\
\text { effort into } \\
\text { what a child } \\
\text { does }\end{array}$ & $\begin{array}{c}\text { enabling child } \\
\text { to know what } \\
\text { is good }\end{array}$ & $\begin{array}{c}\text { setting } \\
\text { realistic } \\
\text { expectations }\end{array}$ \\
\hline $\begin{array}{l}\text { parents and their } \\
\text { way of education }\end{array}$ & $-0,027$ & 0,047 & 0,073 & $-0,107$ \\
\hline $\begin{array}{l}\text { professional and } \\
\text { popular literature }\end{array}$ & 0,068 & $0,198^{*}$ & $-0,052$ & $-0,061$ \\
\hline parent's intuition & $-0,021$ & 0,095 & 0,120 & 0,154 \\
\hline $\begin{array}{l}\text { teachers in } \\
\text { kindergarten }\end{array}$ & 0,130 & 0,006 & $-0,006$ & $0,341^{* *}$ \\
\hline professional team & 0,064 & 0,106 & $-0,013$ & 0,104 \\
\hline
\end{tabular}

$* *$ correlation significant with $p<0,01 ; *$ correlation significant with $p<0,05$

In Table 10 it is noticeable that the correlations between sets of variables Parental encouraging self-esteem in children and Information that parents receive from teachers about the child about the young child's development of his self-esteem are not statistically significant (none of the possible 16 correlations). These two sets of variables are not interrelated.

Table 10 Correlations between sets of variables Parental encouraging self-esteem in children and Information that parents receive from teachers about the child

\begin{tabular}{|l|c|c|c|c|}
\hline \multicolumn{1}{|c|}{ Variable } & \multicolumn{4}{|c|}{ The kindergarten teachers provided information regarding } \\
\hline $\begin{array}{l}\text { Parental encouraging } \\
\text { self-esteem through ... }\end{array}$ & $\begin{array}{c}\text { problem } \\
\text { solving and } \\
\text { effort }\end{array}$ & independence & $\begin{array}{c}\text { reactions to } \\
\text { success and } \\
\text { failure }\end{array}$ & $\begin{array}{c}\text { relationship } \\
\text { with other } \\
\text { children }\end{array}$ \\
\hline $\begin{array}{l}\text { express their own } \\
\text { opinions }\end{array}$ & 0,188 & 0,166 & 0,070 & 0,028 \\
\hline $\begin{array}{l}\text { investment the effort into } \\
\text { what a child does }\end{array}$ & 0,143 & 0,070 & 0,087 & 0,017 \\
\hline $\begin{array}{l}\text { enabling child to know } \\
\text { what is good }\end{array}$ & $-0,043$ & $-0,004$ & $-0,081$ & $-0,111$ \\
\hline $\begin{array}{l}\text { setting realistic } \\
\text { expectations }\end{array}$ & 0,119 & 0,057 & 0,128 & 0,177 \\
\hline
\end{tabular}

Table 11 shows the relationship between sets of variables Information that parents receive from teachers about the child and Kindergarten's assistance in the development of self-esteem in children. From a total of 20 correlations, 11 were statistically significant. Among the ways how the kindergarten try to help in the development of self-esteem in children, the largest number of statistically significant positive (albeit low to medium-high) correlations have the proper treatment of children 
by teachers, educators often providing good quality information about the children. These two variables are correlated with all areas of child development and behavior. Information about the child's independence, the reactions to success and failure, and relationships with other children are associated positively and significantly not only with these two variables, but also with parents' meetings on a particular topic. On average, these two sets of variables are moderately well-correlated.

Table 11 Correlations between sets of variables Information that parents receive from teachers about the child and Kindergarten's assistance in the development of self-esteem in children

\begin{tabular}{|l|c|c|c|c|c|}
\hline \multicolumn{1}{|c|}{ Variable } & \multicolumn{5}{|c|}{ Kindergarten's assistance in developing self-esteem } \\
\hline $\begin{array}{l}\text { The kindergarten } \\
\text { teachers provided } \\
\text { information regarding }\end{array}$ & $\begin{array}{c}\text { proper } \\
\text { teacher's } \\
\text { treatment of } \\
\text { children }\end{array}$ & $\begin{array}{c}\text { often } \\
\text { provide } \\
\text { good quality } \\
\text { information }\end{array}$ & $\begin{array}{c}\text { advice } \\
\text { from the } \\
\text { expert } \\
\text { team }\end{array}$ & $\begin{array}{c}\text { parental } \\
\text { meetings on } \\
\text { a particular } \\
\text { topic }\end{array}$ & $\begin{array}{c}\text { no need } \\
\text { for help } \\
\text { from the } \\
\text { kindergart } \\
\text { en }\end{array}$ \\
\hline $\begin{array}{l}\text { problem solving and } \\
\text { effort }\end{array}$ & $0,321^{* *}$ & $0,351^{* *}$ & 0,121 & 0,144 & 0,022 \\
\hline independence & $0,348^{* *}$ & $0,417^{* *}$ & 0,100 & $0,251^{*}$ & $-0,014$ \\
\hline $\begin{array}{l}\text { reactions to success } \\
\text { and failure }\end{array}$ & $0,418^{* *}$ & $0,446^{* *}$ & 0,108 & $0,198^{*}$ & 0,017 \\
\hline $\begin{array}{l}\text { relationship with } \\
\text { other children }\end{array}$ & $0,477^{* *}$ & $0,464^{* *}$ & 0,108 & $0,244^{*}$ & $-0,083$ \\
\hline
\end{tabular}

$* *$ correlation significant with $p<0,01 ; *$ correlation significant with $p<0,05$

The main findings of the research are the variables which are well and positively correlated and which belong to the same group of variables, related to the various factors that affect the development of the child's self-esteem, both at home and in the kindergarten (1). Therefore, parents (especially mothers) tend to perceive that experts from kindergarten provide the coordinated help in the development of child's selfesteem, giving parents the essential information about the different development areas simultaneously. Parents (according to their own perception) tend to stimulate multifaceted development of their child's self-esteem. Exceptions are the sources of knowledge about the development of self-esteem in children, where mothers tend to prefer only some sources as more relevant in encouraging the self-esteem of the child.

On the other hand, different groups of variables that describe the various factors affecting the development of the child's self-esteem (both at home and in the kindergarten) are quite worse correlated (2). Multiple positive correlations we found between the groups of variables kindergarten's help in developing self-esteem, and information that parents receive from educators about the child: the mothers' perception is that the kindergarten's staff make the efforts to stimulate a child's self-esteem, which is reflected in providing information to parents about the child's behavior and the progress in development.

Correlation between sets of variables of sources of knowledge about the development of self-esteem in children and information that parents receive from 
educators about the child, could be tentatively interpreted as a better opportunity that (in terms of children's self-esteem) more educated parents could recognize the indicators about child's level of self-esteem, through the information they receive from educators from kindergarten about child's behavior and his/her development.

However, we must not forget the fact that mother's estimates the level of the child's self-esteem are rather high, as same as for the kindergarten's contribution to the child's self-esteem level. At the same time, it does not mean that there is no "space" enough for the further improvement, by the coordinated efforts of parents and professionals from a kindergarten in this regard.

The practical application of these results, we see in the purpose of education of parents and educators, with a stated aim (coordinated efforts in stimulating children's self-esteem). A successful parenting is still a lot of talking, looking for the ideal pattern for dealing with unpleasant situations, and with the purpose to help children to grow in quality people. But in the reality there is no universal "recipe" for it. At the parents, we should move the focus of attention from solving problems, on the situations when they occur, to daily treatment with children, and building quality relationships. It is important to raise awareness of what it means to truly accept, support the child, set the boundaries to the child, simultaneously avoiding to compromise his integrity. We can give them the knowledge that such way tends to build a positive image in the child about himself/herself and very positive self-esteem, as a good basis for developing a healthy and good personality. It also reinforces the sense of competence of the parents, what again contribute to strengthening parent-child relationship. It is important to teach educators the same. It turned out that, despite teachers should have more knowledge comparing to children's parents, they often act like the parents, they have very similar prejudices in the education. With the parents, kindergarten professionals can arrange a series of communicative parent-teacher meetings, with many topics to cover: recognition, understanding and satisfying the child's needs, awareness of their own boundaries, placing the child's boundaries; to accept a child with a gesture and the words, consistency (not) always, support and assistance in selecting and modeling of behaviors directed to a child. Teachers can be trained about the same topics through different forms of professional training. In working with educators we must still include the topics: the role of educators in promoting self-esteem in children; own self-image, how to inform parents about their child's achievement, the impact of social comparisons on the self-esteem. For the kids, we can create small projects that could be done within the educational group: for example, It's me, What can I do?, I and my friends, etc.

This way of education and the activities could be used for the future research. Before and after training, we can estimate the rearing practices and self-esteem of children, and compare the results to see whether some specific type of education affects the self esteem of children. We can also consider the more appropriate use of some educational methods.

A major drawback of this study is the small number of participants. In addition, we didn't took into account potentially relevant demographic data such as age and sex of the child, the mother's age, (un) employment status of the mothers, the integrity of the child's family, mother's level of qualification. One possibility is that future research 
take a focus on the constructs of self-esteem and parenting practices separately. In this way, we could include more variables and get a complete picture about the constructs. We could answer the questions about the factors affecting the prediction of self-esteem in children, the extent to which self-esteem changes with the benefit of hindsight, whether the time lag is changing self-esteem of the boys and girls. Also, using longitudinal research, we could see if the parents' actions change in a function of child's age. The variables of parental practices, (un) employment, living in the (non) coherent family, we believe that they are in interdependence with the experience of stress and certain personality characteristics of parents. So it would be useful to explore them. Also, it would be useful to detect whether the procedures in education differ between educators and parents, and whether parents and teachers assess equally the level of the self-esteem of children.

\section{Conclusion}

In the first group of hypotheses, we assumed that there were statistically significant correlations within sets of variables: the type of information that parents receive from educators in the kindergarten, kindergarten assistance in developing selfesteem of the child; sources of knowledge about the development of self-esteem in children, encouraging parental self-esteem in children. All the hypotheses are supported, except one for the intercorrelation of different sources of knowledge about the development of self-esteem in children (which are not significantly correlated).

In the second group of hypotheses, we assumed that there were no statistically significant correlations between the sets of variables: the type of information that parents receive from educators in kindergarten, parental encouragement of self-esteem in children; kindergarten's helping children in developing self-esteem; sources of knowledge about the development of self-esteem in children. However, it turns out that we can support the null hypothesis of crosscorrelations between the sets of variables: sources of knowledge about the development of self-esteem in children and kindergarten's help in development self-esteem in children, kindergarten's help to develop child's self-esteem and parental encouragement of self-esteem in children; sources of knowledge about the development of self-esteem child and encouraging parental self-esteem in children, parental self-esteem by encouraging children and information that parents receive from educators about the child's development of his self-esteem. We reject the null hypothesis for crosscorrelations between the sets of variables: kindergarten's help in developing self-esteem and information that parents receive from the educators about the child; sources of knowledge about the development of self-esteem in children and information that parents receive from the educators about the child.

These results show at first that mothers generally show the interest in developing self-esteem in children, and that they perceive the importance of their own (parental) roles, the importance of the preschool institution (kindergarten), but also the 
coordination of joint efforts of the parents and preschool institution, used to encourage the child's self-esteem.

\section{References} middle

COLLINS, W.A. \& RUSSELL, G. (1991), Mother-child and father-child relationship in childhood and adolescence: A developmental analysis. In: Developmental Review, Vol. 11, pp.

99-136.)

COOPERSMITH, S. (1967), Parental characteristics related to self-esteem. In: The antecedents of self-esteem (Chapter 6, pp. 96-117), San Francisco: Freeman.

FELSON, R.B., \& ZIELINSKI, M.A. (1989), Children's self-esteem and parental support. (In: Journal of Marriage and the Family, Vol. 51, pp. 727-735)

DARLING, N. \& STEINBERG, L. (1993), Parenting style as context: An integrative model.

(U: Psychology Bulletin, Vol. 113, No. 3, pp. 487 - 496)

EDEIMAN, L.(1994), 39 Ideas for Involving Parents in Program for Young Children, Washington D. C: Georgetown University, Child Development Center.

HARTER, S. (1999), The construction of the self- a developmental perspective, New York: Guilford Publications, Inc.

$\&$

PETERSON, G.W. \& ROLLINS, B.C. (1987), Parent - child socialization. (In: M.B. Sussman

S.U. Steinmetz (Ed.), Handbook of marriage and the family, pp. 471 - 507 New York:

Plenum.)

PETROVIĆ-SOČO, B. (1995), Ispitivanje stavova roditelja o suradnji s dječjim vrtićem, Zagreb: Filozofski fakultet.

ROSENBERG, M. (1965), Society and the adolescent self-image, Princeton, NJ: Princeton University Press.

ROSENBERG, M (1968), Psychological selectivity in self-esteem formation. (In: C. Gordon \& K.J. Gergen (Ed). The self in social interaction. New York: John Wiley \& Sons.)

ROSENBERG, M., \& PEARLIN, L.I. (1978), Social class and self-esteem among children and adults. (In: American Journal of Sociology, Vol. 84, pp. 53-77 ) 
Metodički obzori 10, vol. 5(2010)2

Original scientific paper

UDK: 159.923.9-053.4

Received: 21. 9. 2010.

POVEZANOST ČIMBENIKA VEZANIH UZ POTICANJE SAMOPOŠTOVANJA PREDŠKOLSKE DJECE U DJEČJEM VRTIĆU

\author{
dr. sc. Joško Sindik \\ Sveučilište u Dubrovniku, Dubrovnik \\ E-mail: josko.sindik@hinet.hr \\ Dijana Frančešević, dipl. psiholog \\ Dječji vrtić «Kustošija», Zagreb \\ Narcisa Vojnović, M.S. \\ Education and Teacher Training Agency, Zagreb \\ Ida Šimunović, dipl. psiholog \\ Dječji vrtić «Tratinčica», Koprivnica
}

\begin{abstract}
Sažetak
Samopoštovanje, važan aspekt samopoimanja, termin je kojim se izražava globalno vrednovanje sebe. Koordinirano stimuliranje razvoja djetetova samopoštovanja djece od strane roditelja i predškolske ustanove, važan je preduvjet djetetova cjelokupnog psihofizičkog razvoja. Cilj ovog rada odnosi se na utvrđivanje interkorelacija unutar skupova varijabli te kroskorelacija između skupova varijabli: vrsta informacija koje roditelji dobivaju od odgojiteljica u vrtiću, pomoći vrtića u razvoju samopoštovanja djeteta, roditeljskog poticanja samopoštovanja te izvora znanja o razvoju samopoštovanja kod djeteta. Sudionice istraživanja bile su prigodni uzorak od 102 majke koje su u prosincu 2009. godine imale djecu uključenu u programe predškolskih ustanova u Hrvatskoj. Primijenili smo Upitnik o roditeljskoj percepciji poticanja samopoštovanja u dječjem vrtiću. S izuzetkom izvora znanja o djetetovom samopoštovanju, pokazalo se da postoje statistički značajne povezanosti unutar svih ostalih skupova varijabli koje se odnose na poticanje djetetova samopoštovanja. S druge strane, mali je broj statistički značajnih povezanosti između različitih skupova varijabli, pa su jedino vrste i informacija koje roditelji dobivaju od odgojiteljica o djetetu povezane statistički značajno s različitim izvorima saznanja o djetetovu samopoštovanju, ali i podacima koje im daju odgojiteljice o djetetu. Rezultati pokazuju da majke općenito pokazuju interes za razvoj samopoštovanja kod djece, i da u tome percipiraju važnost vlastite (roditeljske) uloge, važnost predškolske ustanove, ali i koordinacije zajedničkog napora roditelja i predškolske ustanove u funkciji poticanja djetetova samopoštovanja.
\end{abstract}

Ključne riječi: djeca, samopoštovanje, povezanost, dječji vrtić, roditelji 
APPENDIX - Questionnaire about parental perception of encouraging selfesteem in kindergarten (Simunovic, 2007)

Child's Age: Gender: $\mathrm{M} \quad \mathrm{F}$

From which sources you get knowledge about the development of self-esteem in children (circle for each answer: $2=$ often, $1=$ occasionally, $0=$ rarely, never):

a) We are working as our parents did 210

b) We read a lot of professional and popular literature on child-rearing 210

c) We take the intuition in education and thus in this 210

d) The teacher of kindergarten or informing the individual parent meetings 210

e) By a professional team through reading articles or at the parent meetings 210

How do you see the help in developing self-esteem of your child by kindergarten (circle for each answer: 2 = often, 1 = occasionally, 0 = rarely, never):

a) by proper educator's behavior oriented to the child in kindergarten 210

b) with more often and better information provided about my child 210

c) counselling by a professional team 210

d) parent-teacher meetings on a particular topic 210

e) we do not need kindergarten's help 210

What information about your child do you get from educators (circle for each answer: 2 = often, 1 = occasionally, 0 = rarely, never):

a) How does he/she solve some task, whether he/she tries to solve the task 210

b) Is he/she independent 210

c) How does he/she reacts to success and failure 210

d) How is his relationship with other children like 210

How do you try to stimulate the self-esteem in your child (circle for each answer: $2=$ often, 1 = occasionally, $0=$ rarely, never):

a) encourage him / her to express his / her opinions 210

b) encourage him / her to put a lot of effort into things what he / she does 210

c) we try to take him / her clear when something is made wrong or well 210

d) we set realistic expectations for what can be achieved with regard to the child's age 210

How much do you think you are successful in stimulating the self-esteem in your child (circle one answer):

a) Fully

b) Partially, we are not sure if it's good we do or something we can improve

c) Not at all, we do not know what to do 
Are you satisfied with the self-esteem of your child (circle one answer):
a) we are
b) we are, but we would like that our child is more persistent
c) we aren't

The kindergarten does a lot in developing self-esteem of children (circle one answer):
a) Yes b) We don't know c) No
b) Are you informed by educators about the level of development and the ways of encouraging self-esteem of your child's in the kindergarten (circle one answer):
c) a) yes, regularly b) sometimes c) never or almost never 